\title{
ANALISIS PENGUNGKAPAN UNIVERSITY SOCIAL RESPONSIBILITY DI UIN MAULANA MALIK IBRAHIM MALANG
}

\author{
Noval Gibran Lubis*, Endang Dwi Wahyuni, Siti Zubaidah \\ Program Studi Akuntansi Fakultas Ekonomi dan Bisnis \\ Universitas Muhammadiyah Malang \\ Jl. Raya Tlogomas No. 246 Malang
}

*Corresponding author: novalgibran22@gmail.com

\begin{abstract}
The purpose of this research is to analyze the implementation of green accounting based on university social responsibility UIN Maulana Malik Ibrahim Malang. Respondents in this study were 43 employees at the Maulana Malik Ibrahim State Islamic University Malang. Data acquisition techniques in this study are questionnaires and documentation. This research is descriptive. The results indicate that 1) environmental awareness has a tendency for data with a percentage of $74.00 \%$ or in the good category. 2) environmental involvement has tendency of data with percentage 69.09\% or mauk in good category. 3) environmental reporting has a 55.58\% data trend or is categorized as sufficient. 4) environmental audits also have tendency of data with percentage 59,67\% or included in enough category.
\end{abstract}

Keywords: University Social Responsibility, Enviromental awareness, Enviromental Involvement, Enviromental Reporting, Enviromental Auditing

\section{PENDAHULUAN}

Isu-isu mengenai lingkungan banyak dibicarakan belakangan ini. Penyebabnya ialah perubahan iklim global yang disebabkan oleh maraknya pembangunan dan kegiatan-kegiatan industri yang dilakukan oleh perusahaan sekarang ini. Tidak dapat dipungkiri pesatnya perkembangan industri dan teknologi yang canggih menimbulkan efek terhadap lingkungan sekitar. Dimana pelaku industri seringkali mengabaikan dampak yang ditimbulkan bagi lingkungan, seperti timbulnya polusi udara, air, tanah dan adanya kesenjangan sosial terhadap lingkungan. Dari hal tersebutlah yang akhirnya menimbulkan kesadaran akan pentingnya menjaga alam dan tidak mengkesampingkan lingkungan sekitar, salah satunya dari sisi akuntansi yaitu dengan mengusung

Diterima 16 Sep 2018 Direviu 21 Sep 2018 Direvisi 30 Okt 2018 Diterima 4 Nov 2018

Artikel ini tersedia di website : http://ejournal.umm. ac.id/index.php/jaa green accounting.

Menurut Sari dan Hadiprajitno (2013) mngatakan bahwa, "konsep green accounting ini sudah mulai diperkenalkan dan dibahas sejak tahun 1970-an di Eropa. Menurut Djogo (2006) di negara-negara maju yang ada di Eropa dan Jepang, perhatian mengenai akuntansi lingkungan ini berkembang sangat pesat baik secara teori maupun praktiknya. Pengungkapan akuntansi lingkungan dinegara berkembang masih sangat kurang, Ratnasari (2011) berpendapat bahwa kurangnya pengungkapan akuntansi lingkungan di negara berkembang disebabkan karena lemahnya hukum tentang lingkungan yang ada di negara tersebut. Serupa dengan Ratnasari, Lindrianasari (2007) juga berpendapat bahwa salah satu faktor kurangnya pengungkapan akuntansi lingkungan karena lemahnya hukum yang berlaku di negara tersebut. 
Bukan hanya perusahan saja yang terkena dampak dari kesadaran masyarakat akan hal ini. Perguruan tinggi juga terkena dampak akan tanggung jawab sosial dan lingkungan. Dalam perguruan tinggi, tanggung jawab sosial dan lingkungan perusahaan disebut University social Responsibilities (USR). University Social Responsibilities (USR) merupakan suatu kebijakan etis yang akan sangat mempengaruhi kualitas kinerja suatu perguruan tinggi yang di dalamnya meliputi mahasiswa, pengajar, seluruh karyawan, dan seluruh pengelola perguruan tinggi melalui manajemen yang bertanggungjawab terhadap dampak pendidikan, kognitif, ketenagakerjaan dan lingkungan yang dihasilkan oleh perguruan tinggi melalui interaksi dengan masyarakat dalam rangka menghasilkan pembangunan manusia yang berkesinambungan (Sari dan Hadiprajitno : 2013). University Social Responsibility sendiri pada dasarnya adalah bentuk Corpporate Social Responsibility (CSR) yang diterapkan diperguruan tinggi. CSR adalah mekanisme organisasi secara sukarela mengintegrasikan perhatiannya terhadap lingkungan dan masyarakat ke dalam operasinya dan interaksinya dengan stakeholders yang melebihi tanggung jawab organisasi di bidang hukum (Andiyanto, 2016).

Astiti (2014) menjelaskandalam penelitiannya, bahwa di Indonesia standar akuntansi yang dipakai sebagai acuan belum mewajibkan perguruan tinggi untuk mengungkapkan informasi sosial yang berkaitan dengan kegiatan yang dilaksanakan, khususnya tanggung jawab perguruan tinggi terhadap dampak lingkungan akibat dari kegiatan yang dilakukan.

Ignastia (2017) yang mengambil topik serupa namun memilih objek Universitas Brawijaya Malang. Pada Universitas Brawijaya Malang juga sudah menerapkan green accounting berbasis University Social Responsibility (USR), bahkan disebutkan Universitas Brawijaya Malang merupakan salah satu pelopor green accounting berbasis University Social Responsibility (USR) di Kota Malang. Namun dari 4 item yang ada juga tidak semuanya dilaksanakan dengan maksimal

Di UIN Maulana Malik Ibrahim Malang sendiri tiap tahunnya menerima lebih dari 3.000 mahasiswa baru. Hal ini tentunya akan sangat berdampak bagi kampus itu sendiri maupun bagi lingkungan sekitar, diantaranya bertambahnya tingkat pencemaran polusi yang diakibatkan kendaraan bermotor, bertambahnya kebutuhan lahan untuk mengakomodasi pertambhan jumlah penduduk, serta semakin tingginya penggunan sumber daya energi yang ada di Kota Malang khususnya di lingkungan UIN Maulana Malik Ibrahim Malang. Oleh karena itu penting bagi UIN Maulana Malik Ibrahim Malang untuk memperhatikan dan mempertimbangkan dampak lingkungan yang diakibatkan dari aktivitas operasinya. Di UIN Maulana Malik Ibrahim mulai sadar tentang pentingnya lingkungan sebagai salah satu penunjang sistem pembelajaran di kampus. Bentuk kesadaaran yang dilakukan ialah penghijauan yang dialkukan didalam kampus, diperbanyaknya tempat pembuangan sampah di area kampus.

University Social Responsibility memiliki 4 item penting mengenai kesadaran akan lingkungan dan 4 item tersebut juga menjadi rumusan masalah dalam penelitain ini yaitu tingkat Kepedulian Lingkungan (Environmental Awarness), Keterlibatan Lingkungan (Environmental Involvement), Pelaporan Lingkungan (Environtmental Reporting), dan Audit Lingkungan (Environmental Audit) (Teoh \& Thong ,1986 dalam Yosef, 2003). Sehingga dari 4 indikator tersebut dapat dideskripsikan implementasi Green Accounting berbasis University Social Responsibility (USR) di UIN Maulana Malik Ibrahim Malang. 
Berdasarkan uraian dari latar belakan maka peneliti tertarik untuk menganalisis dan mengetahui sejauh mana UIN Maulana Malik Ibrahim Malang telah melakukan tanggung jawab sosialnya dengan menerapkan University Social Responsibility (USR) dalam aktivitas operasinya.

\section{METODE}

Jenis penelitian yang digunakan oleh peneliti kali ini yaitu menggunakan jenis penelitian deskriptif kantitatif. Dengan mendeskripsikan disertai dengan data statistik bagaimana penerapan atau implementasi University Social Responsibility (USR) yang diterapkan oleh Universitas Islam Negeri Malang. Populasi yang dipilih dalam penelitian ini adalah para pejabat di UIN Maulana Malik Ibrahim Malang yang berada di Gedung Rektorat dan terdapat unit unit didalamnya. Unit-unit yang dipilih terdiri dari Bagian Umum, Bagian Keuangan, Biro Administrasi Akademik (BAA), Satuan Pengawas Internal (SPI), dan LP2M. Dalam penelitian ini juga memilih beberapa dari kalangan mahasiswa yang berada dalam organisasi BEM U di UIN Maulana Malik Ibrahim Malang. Pada penelitian ini peneliti menggunakan metode purposive sampling. Dimana dari total 5 unit berhasil mendapatkan 51 pejabat yang akan dijadikan sampel dalam penelitian ini dan 35 mahasiswa yang berada dalam organisasi BEM-U. Sehingga total sampel yang ada didalam penelitian kali ini 86 orang. Namun setelah dilakukan pengambilan kembali kuesioner, tidak semua dapat kembali. Sehinggal peneliti hanya mendapatkan total 43 kuesioner yang telah terisi. Pada penelitian ini data diperoleh dengan menggunakan kuisioner, jenis kuisioner yang digunakan adalah kuisioner tertutup dimana dalam kuisioner sudah disediakan jawaban sehingga para responden hanya memilih yang dinyatakan dalam skala likert 1 sampai 5 dengan menyatakan Sangat Setuju (SS), Setuju (S), Tidak Tahu (T), Tidak Setuju (TS), dan Sangat Tidak Seyuju (STS).

Penentuan skor skala likert:

a. SS diberikan skor 5 yang menyatakan bahwa anda setuju dan secara rill item itu ada di UIN Maulana Malik Ibrahim Malang.

b. S diberikan skor 4 yang menyatakan bahwa anda setuju bahwa item itu ada di UIN Maulana Malik Ibrahim Malang.

c. T diberikan skor 3 yang menyatakan bahwa anda tidak mengetahui tentang item tersebut.

d. TS diberikan skor 2 yang menyatakan bahwa anda tidak setuju bahwa item itu ada di UIN Maulana Malik Ibrahim Malang.

e. STS diberikan skor 1 yang menyatakn bahwa anda tidak setuju dan secara rill item itu tidak ada di UIN Maulana Malik Ibrahim Malang.

\section{Teknik Analisis Data}

Teknik analisis yang dilakukan pada penelitian ini pertama dengan melakukan uji validitas dan reliabilitas terhadap kuesioner yang telah diajukan kepada UIN Maulana Malik Ibrahim Malang dengan menggunakan SPSS. Uji validitas digunakan untuk menunjukan sejauh mana alat ukur yang digunakan dalam mengukur apa yang diukur. Kemudian melakukan analisis deskriptif yang berfokus pada penyebab munculnya perhatian dari perguruan tinggi terhadap permasalahan lingkungan yang ada, serta menunjukan dalam kondisi seperti apa 
perguruan tinggi memberikan perhatian terhadap lingkungan, termasuk juga keterlibatan akan lingkungan, pelaporan akuntansi lingkungan dan audit terhadap lingkungan. Dengan menggunakan standar penilaian sebagai berikut:

Sebelum mendapatkan hasil interpretasi, terlebih dahulu harus mendapatkan total skor dari responden baik yang menjawab Sangat Tidak Setuju (1), Tidak Setuju (2), Netral/Tidak tahu (3), Setuju (4), dan Sangat Setuju (5), dengan rumus sebagai berikut:

$\mathrm{T}=$ total jumlah responden yang memilih

Pn $=$ pilihan angka skor likert

Sangat Tidak Setuju $=\mathrm{T} \times \operatorname{Pn}(1)$

Tidak Setuju $\quad=\mathrm{T} \times \operatorname{Pn}(2)$

Netral/Tidak Tahu $=\mathrm{T} \times \operatorname{Pn}(3)$

Sangat Setuju $\quad=\mathrm{T} \times \operatorname{Pn}(5)$

Setuju $\quad=\mathrm{T} \times \operatorname{Pn}(4)$

Dari perhitungan diatas dapat mengetahui Total Skor untuk melakukan perhitungan indeks. Kemudian menentukan nilai tertinggi (Y) dan nilai terendah (X) untuk item penilaian dengan rumus sebagai berikut:

$\mathrm{Y}=$ skor tertinggi likert $\mathrm{x}$ jumlah responden

Untuk skor tertinggi $5 \times 86=430$

$\mathrm{X}=$ skor terendah likert $\mathrm{x}$ jumlah responden

Untuk skor terendah $1 \times 86=86$

a. Rumus Index \% = Total Skor / Y x 100\%

b. Rumus Interval

$\mathrm{I}=100 /$ jumlah likert

$\mathrm{I}=100 / 5=20$

$\mathrm{I}=20$

Hasil diatas merupakan intervalnya jarak dari terendah $0 \%$ hingga tertinggi $100 \%$. Berdasarkan interval diatas, interpretasi skornya sebagai berikut:

$$
\begin{array}{ll}
0 \%-19,99 \% & =\text { Sangat kurang } \\
20 \%-39,99 \% & =\text { Kurang } \\
40 \%-59,99 \% & =\text { Cukup } \\
60 \%-79,99 \% & =\text { Baik } \\
80 \%-100 \% & =\text { Sangat Baik }
\end{array}
$$

Setelah dilakukan perhitungan terhadap data dari kuesioner, langkah selanjutnya menginterpretasikan hasil dari perhitungan dan data yang telah dikumpulkan. Terakhir Menarik kesimpulan dari semua hasil diatas tentang bagaimana penerapan Green Accounting berbasis USR di UIN Maulana Mali Ibrahim malang. Yang terdiri dari 4 item yaitu Keterlibatan lingkungan, Kepedulian Lingkungan, Pelaporan Lingkungan, dan Audit Lingkungan.

\section{HASIL DAN PEMBAHASAN}

\section{Environmental Awareness}

Terkait dengan Kepedulian lingkungan yang ada di UIN Maulana Malik Ibrahim Malang, dari 11 instrument pengukur terdapat 2 instrument yang tidak valid, sehingga harus dikeluarkan dari perhitungan. Kepedulian lingkungan di 
UIN Maliki Malang mendapatkan skor rata-rata 74,00\%. Kepedulian akan lingkungan tidak dapat berjalan dengan baik apabila tidak mendapatkan dukungan dari pihak internal maupun eksternal. UIN Maliki Malang sudah menunjukannya dengan tingginya tingkat kesadaran dan kepedulian akan lingkungan yang hadir dari setiap elemen yang berada dari dalam maupun luar kampus. Ini menunjukan bahwa kepedulian lingkungan yang ada di kampus tersebut sudah baik. Berdasarkan jawaban dari para responden, berpendapat bahwa:

- Adanya peraturan yang dibuat oleh pimpinan perusahaan mendapatkan skor $72,56 \%$ (baik)

- Adanya pengaruh atau kesadaran dari pihak kampus itu sendiri Mendapatkan skor $76,74 \%$ (baik)

- $\quad$ Adanya kepedulian terkait lingkungan juga didapat dari kesadaran para karyawan dengan mendapatkan skor 73,00\% (baik)

- Para mahasiswa juga turut andil dalam meningkatkan kesadaran UIN Maliki Malang dalam hal kepedulian lingkungan yaitu sebesar 74,89\% (baik)

- $\quad$ Kepedulian lingkungan di UIN juga mendapat pengaruh dari Lembaga Lingkungan Hidup 70,23\% (baik)

- $\quad$ Pengaruh dari Komunitas Lingkungan 72,56\% (baik)

- Dukungan dari SDM dan SDE yang baik juga meningkatkan kepedulian akan lingkungan yang ada di UIN Maliki Malang dengan mendapatkan skor $72,09 \%$ (baik)

- Salah satu syarat untuk menentukan suatu universitas dinilai baik dalam hal kepedulian lingkungan dapat dilihat dari adanya Induk Penelitian dan Pengabdian, di UIN Maliki Malang sendiri sudah memiliki Induk Penelitian dan Pengabdian yang diberi nama LP2M (Lembaga Penelitian dan Pengabdian kepada Masyarakat. Instrument ini mendapatkan skor $77,67 \%$ (baik)

- Penelitian dan Pengabdian terserbut juga sudah direalisasikan dengan baik, dengan skor $76,28 \%$ (baik).

\section{Environmental Involvement}

Setelah dilakukan perhitungan terhadap data yang diperoleh dari para responden untuk instrument Environmental Involvement atau keterlibatan lingkungan, menunjukan hasil bahwa nilai rata-rata keterlibatan lingkungan yang ada di UIN adalah 69,09\% atau dapat dikatakan baik. Hasil tersebut diperoleh dari:

- $\quad$ Ketersediaan dana yang dikeluarkan khusus untuk lingkungan yang ada di UIN mendapatkan skor 72,09\% (baik)

- $\quad$ Ketersediaan program lingkungan mendapatkan skor 66,98\% (baik)

- Adanya studi tentang keselamatan lingkungan hidup hanya mendapatkan skor $62,12 \%$ namun masih dapat dikategorikan baik.

- $\quad$ Ketersediaan Mou antara UIN dengan pihak terkait lingkungan hidup mendapatkan skor $65,12 \%$ (baik)

- Dukungan penelusuran biaya 67,90\% (baik) 
- Adanya investasi untuk lingkungan hidup mendapatkan skor 68,37\% (baik)

- $\quad$ Design kurikulum terkait lingkungan 67,44\% (baik)

- $\quad$ Standar kompetensi lingkungan hidup 69,30\% (baik)

- $\quad$ Pencapaian standar kompetensi lingkungan hidup 69,30\% (baik)

- Kepatuhan terhadap standar lingkungan hidup mendapatkan skor yang cukup tinggi yaitu $75,35 \%$ (baik)

- Terdapat aspek lingkungan hidup dalam proses belajar mengajar di UIN $73,02 \%$ (baik).

\section{Environmental Reporting}

Perhitungan data kuesioner dari para responden terkait pelaporan lingkungan di UIN Maliki Malang, menunjukan bahwa pelaporan lingkungan yang ada di UIN memiliki skor rata-rata 55,58\% saja yang berarti pelaporan lingkungan yang ada di UIN saat ini masih cukup, yaitu tidak buruk namu tidak dapat dikatakan baik juga. Sangat disayangkan karena UIN Maliki Malang sudah memiliki kepedulian lingkungan dan keterlibatan lingkungan yang baik. Hasil tersebut diperoleh dari:

- Laporan kinerja lingkungan hidup yang hanya mendapatkan skor 60,46\%. Skor tersebut masih dapat dikategorikan baik, namun hampir masuk dalam kategori cukup.

- Laporan kinerja dilaporkan secara kontinyu hanya mendapatkan skor $61,86 \%$ (baik), skor tersebut juga hampir masuk kedalam kategori cukup.

- Laporan kinerja dipublikasikan hanya mendapat skor 61,39\%, masih masuk dalam kategori baik.

- $\quad$ Publikasi terkait lingkungan hidup di UIN dapat dikatakan kurang karna hanya mendapatkan skor $38,60 \%$ saja dari para responden.

\section{Environmental Audit}

Audit lingkungan di UIN Maliki Malang juga mendapatkan skor yang dapat dikategorikan cukup karena hanya mendapatkan skor rata-rata 59,67\% saja dari para responden. Hasil tersebut didapat dari:

- Laporan audit terkait lingkungan yang hanya mendapat 62,32\% saja dari para responden.

- SPI terkait Lingkungan hanya mendapat 59,53\% yang dapat dikategorikan cukup.

- $\quad$ Kompetensi SPI terkait lingkungan hanya mendapat 48,37\%.

- Aktivitas SPI terkait dengan lingkungan hanya mendapatkan 57,67\% saja dari para responden yang ada di UIN.

Tabel 1. Hasil Analisis University Social Responsibility di UIN Maulana Malik Ibrahim Malang berdasarkan data kuesioner

\begin{tabular}{ccc}
\hline Item University Social Responsibility & Skor & Implementasi \\
\hline Environmental Awareness & $74,00 \%$ & Baik \\
Environmental Involvement & $69,09 \%$ & Baik \\
Environmental Reporting & $55,58 \%$ & Cukup \\
Environmental Audit & $59,67 \%$ & Cukup \\
\hline
\end{tabular}

Sumber: Data diolah 
Dalam implementasi university social responsibility, hal pertama yang harus dilakukan oleh UIN Maulana Malik Ibrahim Malang adalah membangun kesadaran serta komitmen yang baik akan pentingnya university social responsibility bagi perguruan tinggi. Tentunya hal tersebut harus disosialisasikan kepada seluruh bagian dari perguruan tinggi, karena university social responsibility tentunya tidak dapat terwujud dan berjalan dengan baik apabila tidak adanya dukungan dari setiap element yang ada di perguruan tinggi tersebut.

Berdasarkan analisis diatas dapat dilihat bahwa pimpinan dari UIN Maulana Malik Ibrahim Malang sudah membuat peraturan dan kebijakan mengenai lingkungan hidup dengan mengusung tema Go Green dalam beberapa kegiatan yang dilaksakan oleh perguruan tinggi tersebut. Kesadaran akan pentingnya lingkungan hidup juga muncul dari para element yang ada di UIN Maulana Malik Ibrahim Malang. Dengan adanya dukungan dari SDM (Sumber Daya Manusia) dan SDE (Sumber Daya Ekonomi) yang baik. UIN Maulana Malik Ibrahim Malang juga memiliki unit penelitian dan pengabdian masyarakat yang diberi nama LP2M (Lembaga Penelitian dan Pengabdian Kepada Masyarakat). Tujuan dari dibuatnya untuk menyelenggarakan dan mengembangkan penelitian dan pengabdian kepada masyarakat dengan mengusung misi mengembangkan penelitian sains-teknologi dan sosial-budaya bagi para dosen dan mahasiswa. Dalam hal pengabdian diwujudkan dengan dibuatnya program Kuliah Kerja Mahasiswa atau KKM yang tujuannya adalah untuk mempersiapkan para calon sarjana agar dapat membantu dan mengembangkan potensi masyarakat. Seperti KKM yang diadakan di Desa Tirtomarto Kecamatan Ampelgading, telah mampu membantu masyarakat daerah tersebut untuk mengembangkan potensinya dan membuat area wisata alam baru yaitu Coban Srengenge. Dengan harapan dapat meningkatkan perekonomian dan kesejahteraan masyarakat yang ada di desa tersebut.

Dalam hal mewujudkan akan kepedulian lingkungan yang ada di UIN Maulana malik Ibrahim Malang, Fakultas Sains dan Teknologi rutin mengadakan kenfrensi internasional yang di beri nama The 8th International Conference On Green Teknologi (ICGT). Agenda rutin yang sudah memasuki angka 8 tersebut membahas tentang pemberdayaan riset dasar ilmu pengetahuan yang dianggap penting bagi perkembangan teknologi hijau yang ada di Indonesia, dan berbagai jenis penelitian dan penemuan dalam bidang teknologi harus mengedepankan konsep Go Green. Dengan mengedepankan konsep go green, diharapkan penemuan atau teknologi yang akan dikembangkan mampu meminimalisisr pengguanaan listrik dan memangkas penggunaan bahan bakar yang membahayakan lingkungan. Tentunya hal tersebut dimaksudkan untuk menciptakan keseimbangan agar suatu teknologi dapat dikatakan ramah serta tidak merusak lingkungan.

Pada item kepedulian lingkungan, UIN Maulana Malik Ibrahim Malang memiliki cleaning service yang bertugas untuk memenuhi dan merawat semua sarana prasarana yang ada di UIN Maulana Malik Ibrahim Malang. Cleaning service berada dibawah tanggung jawab Bagian Umum, Bagian Umum sendiri merupakan bagian dari Biro Administrasi Umum, Perencanaan, dan Keuangan. 
Dapat dikatakan bahwa kondisi lingkungan yang bersih, rapi dan nyaman merupakan salah satu penunjang berjalannya proses pelayanan akademik dan kemahasiswaan dengan lancar sehingga menghasilkan hasil kerja dan prestasi yang optimal. Oleh karena itu, UIN Maliki Malang sangat serius dalam menanggapi hal tersebut dengan membuat jadwal mengenai lingkungan yang terstruktur. Perawatan sarana dan prasarana yang ada di UIN Maliki Malang dilakukan pada pagi, siang dan sore hari. Pada pagi hari melakukan pengkondisian terhadap gedung perkantoran dan perkuliahan seperti membersihakn area gedung, toilet dan membuang sampah. Pengkondisian taman juga dilakukan seperti menyapu jalan, halaman dan taman, menyiram seluruh tanaman yang ada, memberi pupuk secara berkala, dan membersihkan kolam. Dengan adanya jadwal tersebut sudah dipastikan sarana dan prasaran yang ada di UIN Maliki Malang terjaga dan terawat dengan baik. Hal ini juga merupakan salah satu upaya UIN Maliki Malang dalam pencapaian standar dengan mempertimbangkan aspek lingkungan hidup.

Program keselamatan juga sudah diterapkan oleh UIN Maliki Malang tepatnya digedung gedung perkantoran dan perkuliahan yang ada di kampus tersebut dengan diberikannya arahan tangga darurat serta disediakannya alat pemadam api disetiap lantai yang ada. Dengan semua hal diatas sudah dapat dipastikan UIN Maliki Malang memiliki biaya aktivitas terkait lingkungan dan juga tentunya terdapat investasi terkait lingkungan hidup yang ada di UIN Maliki Malang.

Berdasarkan penelitian tentang pelaporan lingkungan yang ada di UIN Maliki Malang, dari 4 instrument yang menjadi pengukur pelaporan lingkungan, sebagian besar responden menjawab "netral/tidak tahu" mengenai hal tersebut dan tidak sedikit juga yang menjawab "tidak setuju" bahwa hal tersebut telah diterapkan di UIN Maliki Malang. Hal tersebut sangat disayangkan karena hanya sedikit saja yang mengetahui prihal publikasi terkait lingkungan yang ada di UIN Maliki Malang. Sebenarnya pada website resmi milik UIN Maliki Malang, pelaporan kegiatan mengenai lingkungan sudah sering dipublikasikan pada website resmi yang dimiliki UIN Maliki Malang. Hal tersebut berarti kegiatan publikasi dilakukan secara kontinyu atau terus menerus. Tetapi tidak ada ditemukan publikasi mengenai biaya khusus terkait lingkungan hidup. Hal ini menyebabkan tidak adanya transparansi UIN Maliki Malang terhadap publikasi mengenai biaya khusus. Tentunya biaya yang didapatkan dan dikeluarkan sangat besar, dan akan sangat baik jika hal tersebut dapat di laporkan dan dipublikasikan agar karyawan dan mahasiswa mengetahui bagaimana kinerja UIN Maliki Malang dalam mengelola keuangannya terhadap lingkungan.

Pada item audit lingkungan, para responden juga banyak yang menjawab "netral/tidak tahu" mengenai hal tersebut dan hanya sedikit pula yang setuju akan hal tersebut. Sebenarnya UIN Maliki Malang sudah memiliki SPI yang mengususng konsep menjadi Satuan Pengawas Internal yang independen serta memliki dedikasi dan profesionalisme yang tinggi untuk mendorong terciptanya good university governance. SPI pada UIN Maliki Malang memiliki tugas pengawasan meliputi seluru proses kegiatan audit, reviu, evaluasi, pemantauan dan kegiatan pengawasan lain terhadap penyelenggaraan tugas dan fungsi 
organisasi yang bertujuan untuk mengendalikan kegiatan, mengamankan harta dan aset, meningkatkan efektivitas dan efesiansi dari kegiatan operasional, kehandalan laporan keuangan, mendeteksi secara dini terjadinya penyimpangan dan ketidaktataan dengan peraturan dan perundangan yang berlaku.

Dilihat dari pernyataan tersebut, dapat dikatakan bahwa hampir setiap kegiatan operasional kampus tidak ada yang luput dari perhatian dari pihak SPI UIN Maliki Malang. Namun tidak ada disebutkan aktivtas SPI yang terkait akan lingkungan yang ada di UIN Maliki Malang.

University Social Responsibility di UIN Maulana Malik Ibrahim Malang Berdasarkan dari hasil penelitian tiap item dan instrumen diatas, dapat dikatakan bahwa UIN Maliki Malang sudah baik dalam menerapkan USR. Hal tersebut dibuktikan dengan item kepedulian lingkungan yang baik, didukung dengan adanya kegiatan yang mengusung konsep go green dan UIN Maliki juga memiliki lembaga pengabdian dan penelitian kepada masyarakat dan telah direalisasikan sampai saat ini. Kesadaran yang tinggi akan lingkungan juga dibuktikan dengan dukungan pihak perguruan tinggi dalam meciptakan atau mengembangkan teknologi yang ramah akan lingkungan. Keterlibatan UIN Maliki terhadap lingkungan juga baik, hal ini dibuktikan adanya unit yang mengurus sarana dan prasarana sektiar agar tetap terawat dan bersih. Dengan membuat jadwal yang terstruktur dengan baik tentunya akan sangat menjaga sarana dan prasarana yang ada di UIN Maliki Malang. Program keselamatan juga sudah diterapkan dengan baik pada UIN Maliki Malang. Pelaporan lingkungan terkait biaya khusus lingkungan yang dikeluarkan masih belum dipublikasikan sehingga menimbulkan ke-tidak transparan UIN Maliki Malang dalam hal tersebut. Audit terhadap lingkungan dinilai cukup karena UIN maliki Malang pada dasarnya sudah memiliki SPI yang bekerja sesuai dengan porsinya. Hal tersebut tentunya sangat baik, namun dinilai kurang karena masih belum ada dijelaskan kegiatan SPI yang berkaitan dengan lingkungan di UIN Maliki Malang.

\section{SIMPULAN}

Berdasarkan dari beberapa analisis yang dilakukan dapat disimpulkan bahwa environmental awareness dan environmental involvement masuk dalam kategori baik. Sedangkan pada item environmental reporting mendapatkan nilai yang cukup dan untuk item environmental audit juga masuk dalam kategori cukup. Secara keseluruhan University Social Responsibility yang ada di UIN Maulana Malik Ibrahim Malangsudah dapat dikatakan baik karena hampir seluruh instrument sudah terpenuhi.

\section{DAFTAR PUSTAKA}

Astiti, W. 2014. "Implementasi green accounting berbasis University Social Responsibility (USR) di Universitas Negeri Yogyakarta". Nominal, Barometer Riset Akuntansi dan Manajemen, Vol. 3, No. 2, hlm.

Astuti, N. 2012. "Mengenal green accounting". Permana, Vol. 4, No. 1.

Djogo, T. 2006. Akuntansi Lingkungan (Environmental Accounting): Konphalindo. www. beritabumi. com.

Harahap, S. S. 2001. Analisa kritis atas laporan keuangan: RajaGrafindo Persada. 
Ignastia, C. D. 2017. "Implementasi Green Accounting Berbasis University Social Responsibility (Usr) Di Universitas Brawijaya". Jurnal Ilmiah Mahasiswa FEB, Vol. 5, No. 2.

Jahamani, Y. F. 2003. "Green accounting in developing countries: The case of UAE and Jordan". Managerial Finance, Vol. 29, No. 8. 37-45.

Lindrianasari, L. 2007. "Hubungan Antara Kinerja Lingkungan dan Kualitas Pengungkapan Lingkungan dengan Kinerja Ekonomi Perusahaan di Indonesia". Jurnal Akuntansi dan Auditing Indonesia, Vol. 11, No. 2.

Musyarofah, S. 2013. "Analisis Penerapan Green Accounting di Kota Semarang". Accounting Analysis Journal, Vol. 2, No. 3.

Ratnasari, Y., dan A. Prastiwi. 2010. "Pengaruh Corporate Governance terhadap Luas Pengungkapan Tanggung Jawab Sosial Perusahaan di dalam Sustainability Report", Universitas Diponegoro.

Rosiana, G. A. M. E., G. Juliarsa, dan M. M. R. Sari. 2013. "Pengaruh pengungkapan CSR terhadap nilai perusahaan dengan profitabilitas sebagai variabel pemoderasi". E-Jurnal Akuntansi. 723-728.

Sari, M. P., dan P. B. Hadiprajitno. 2013. "Pengawasan Impelementasi "Green Accounting” Berbasis University Social Responsibilities (Usr) Di Universitas Negeri Semarang Serta Studi Komparasi Universitas Se-kota Semarang". Jurnal Akuntansi dan Auditing, Vol. 9, No. 2. 169-198.

Ulum, I., dan A. Juanda. 2016. Metodologi Penelitian Akuntansi. Malang: Aditya Media Publishing.

Andriyanto, M.R. 2016. Pengawasan Implementasi "Green Accounting” Berbasis University Social Responsibility (USR) di Universitas Muhammadiyah Surakarta serta Studi Komparasi Universitas lain di Surakarta. Skripsi. Solo : Universitas Muhammadiyah Surakarta. 